\title{
20. Recent developments in the Limburg dialect region
}

1. About the region of Limburg

2. Dialect use in Limburg

3. Horizontal dialect convergences/divergences under the influence of political borders

4. Dialect convergences/divergences according to the extent of geographical distribution

5. Vertical convergences: Dialect - standard in (apparent) time

6. Desiderata

7. Atlases

8. References

\section{About the region of Limburg}

Unlike other regions in the Netherlands, like Brabant, Holland or Friesland, the province of 'Limburg' has no historical roots predating 1795. Dutch Limburg was artificially created as an administrative district by the French Revolutionary forces, later consolidated in the Kingdom of the Netherlands, where throughout the nineteenth century it remained subject to geopolitical uncertainties (Leerssen 2006). Its integration into the centralization processes of the Dutch state is of recent date (the end of nineteenth century), and many cultural and linguistic (dialect) peculiarities were maintained at a regional level as part of a sense of Limburg peripherality.

In Limburg, the codification and promotion of local varieties started early, already at the end of the nineteenth century. Both the urban bourgeoisie and the rural clergy in Limburg took an interest in the local language as a foundation of authentic local culture and identity. This interest was consolidated at a time when the primacy of the national language, Dutch, was far from obvious, and challenged by the use of German (along the eastern frontier) or French (mainly in the regional capital of Maastricht, cf. KesselsVan der Heijde 2002). This allowed the dialects to maintain a far stronger social and cultural position than elsewhere in the Netherlands. Nowadays, around 900,000 people or $75 \%$ of the inhabitants in Netherlandic Limburg claim to speak a Limburg dialect (Driessen 2006: 103). The UNESCO Atlas of World Languages in Danger (UNESCO 2009) considers the dialects of Limburg, in particular the Ripuarian ones, endangered languages. Also the Netherlands, a signatory of the 1992 European Charter for Regional Languages or Languages of Minorities, extended minor recognition to the regional languages of Limburg in 1997. (Minor recognition means that the Dutch state formally recognizes the status of the Limburg variety - or varieties - as a separate language without, however, taking relevant measures such as financial support.) The same request by a group of speakers of Belgian Limburg dialects has been turned down in 1999 by the Flemish government, see Belemans 2009), i.e. the government of the northern, Dutchophone part of Belgium.

Speaking a Limburgian dialect is not evaluated as a characteristic of lower social status (Driessen 2006), but as a (positive) expression of regional or local loyalty. In this respect there are huge internal differences within Limburg. Maastricht, a city with a 
long history and a rich tradition, cultivates the local dialect which has a high prestige (Münstermann and Hagen 1986; Hagen and Giesbers 1988; Kessels-Van der Heijde 2002, Extra 2004) although a recent survey reports that the positive attitude towards the local dialect has somewhat decreased lately (Kroon and Vallen (eds.) 2004). A modern industrial city like Heerlen (a former coalmining city), on the other hand, is well known in Limburg for its use of somewhat stigmatized regional SD instead of the local dialect (Cornips 1994).

In Belgium (specifically Flanders, i.e. the northern, Dutch-speaking part of the country), the process of standardization took place much later than in the Netherlands. To be more specific, it only received a wide sociological base since the 1960s (Sijs 2004: 8). Generally speaking, until the 1970s dialect was by far the most dominant code for nonpublic purposes, with a very restricted use of the standard language (Vandekerckhove 2009: 67; Vandekerckhove, chapter 11 in this volume).

From a traditional perspective, the following dialects in the provinces of Limburg in the Netherlands and Belgium can be distinguished on the basis of isoglosses from east (the southern Dutch-German state border) to west in Belgium (cf. Belemans 2009, Hermans, this volume; Keulen et al. 2007): 1) a transitional area between the Ripuarian dialects and the Limburg dialects; 2) East Limburg dialects; 3) Central Limburg dialects; 4) West Limburg dialects; 5) a transitional zone near the city of Genk in between Central and West Limburg; and 6) a transitional zone in between the Brabantic dialects and the West Limburg dialects.

\subsection{The notion of Limburg dialects and the complexity of the verbal repertoires}

The dialects spoken in the provinces of Limburg in the Netherlands and Belgium (Flanders) are naturally heterogeneous systems and although they are very similar they also reveal distinctive grammatical properties. The river Maas (which has marked the border between the Dutch and Belgian provinces of Limburg since 1830) has had clear dialect geographical effects in phonology (see Weijnen [1966: 474] for references; cf. FAND, Vols. II-III, maps 77-82, 92, 94, 100 and 102), but the territorial and administrative borders that constitute the provinces of Limburg do not correspond with linguistically bound entities.

Although Weijnen (1966: 426) discusses Limburgian 'exclusivisms', i.e. historical phonological, phonological, and morphosyntactic features which do not occur in any other Dutch dialect region, the present-day Limburg dialects are fluid entities which cannot be neatly distinguished from other surrounding dialects outside the provinces of Limburg. Moreover, many so-called 'Limburgian' phenomena can be found in the neighbouring dialects in Germany. One example is the Ripuarian reflexive adjunct middle, which also occurs in some German Middle Franconian varieties (cf. Auer 2004: 79, Cornips 1996, Cornips and Corrigan 2005):

(1) Der sal singt sich legt

the hall sings refl easily

'this hall has good acoustics' (lit. ... sings well).' 
A second example is plural formation by means of umlaut, which is considered both a Limburgian and German phenomenon (Belemans and Keulen 2004: 54). Some examples from the dialect of Tongeren (Belgium) are given in (2):

(2) a. knoep 'bud' - knüp 'buds'

b. moêr 'wall' - muûr 'walls'

On the other hand, it is not the case that so-called 'Limburgian' phenomena, such as that in (1), is found everywhere in the province. There is not a single morphological phenomenon that sets apart Belgian Limburg from Netherlandic Limburg or from other surrounding areas (cf. the Morphological Atlas of the Dutch Dialects, Vols I \& II by De Schutter et al. 2005, Goeman et al. 2008 and the Syntactic Atlas of the Dutch Dialects, Vols. I \& II by Barbiers et al. 2005, 2008). Furthermore, there are hardly any phonological phenomena that separate Limburg as a whole from other areas (see Hermans, ch. 18 in this volume).

Dialects nowadays rarely exist in absolute isolation and speakers are bi- and multilingual, that is; they can usually resort to a range of varieties along a continuum from standard language to intermediate varieties to dialect and code-switching varieties, depending on social and discourse contexts. Nowadays, there are no longer any speakers who are truly monolingual in the local dialects in Limburg, i.e. dialect speakers also speak (a variety of) SD. In addition, speakers from outside Limburg who have migrated to Limburg may acquire the local dialect as a second language (Vousten 1995). Immigrants who have settled in Netherlandic Limburg may shift to SD or dialect or either. In Maastricht, for example, about $12 \%$ of the children who speak the dialect of Maastricht live in a household where English, German, French, Italian, Moluccan, Spanish, Arabic or Turkish is also spoken (Extra 2004: 129). In Heerlen, German and Arabic are the languages that are spoken by most pupils. apart from SD and the local dialect (Kroon and Vallen 2004: 21). Accordingly, the dialect is one among the several language codes available from a wider set of choices and it can be mixed with other codes (see section 4.3. below; Giesbers 1988).

\section{Dialect use in Limburg}

\subsection{Limburg in Belgium (Flanders)}

This section reports on functional loss of the dialect. With respect to Dutch-speaking Belgium, as was already mentioned in the introduction, dialect loss is a relatively new but by now a quite general phenomenon. According to Vandekerckhove (2009: 73-79), there is a general tendency towards replacing primary dialect features of a relatively local scope by secondary dialect features that have a wider distribution and/or bear more resemblance to the SD equivalents (see also Auer 2005). The implication is that the old dialects have not made way for a generalized use of (Belgian) SD; instead, Flanders is developing a new diglossia: SD is still reserved for formal domains, but for the younger generations, also in Limburg, the dominant variety for informal colloquial speech is a regional variety, also called tussentaal (lit. intermediate language; cf. Absillis, Jaspers 
and Van Hoof 2012, Geeraerts and Van de Velde, ch. 28 in this volume). Vandekerckhove (2009: 78) discusses two surveys in which students from several universities were questioned about their dialect 'knowledge' in Limburg and elsewhere in Flanders, namely Willemyns in 1979 and Van Keymeulen (1993) fourteen years later. The percentages indicate a decline in the command of the regional dialects geographically and through time. A growing discrepancy can be observed between Limburg (low vitality) and West Flanders (high vitality).

Tab. 20.1: University students claiming to have a good command of a local dialect

\begin{tabular}{lcc}
\hline & $\begin{array}{c}\text { Willemyns (1979) } \\
\%\end{array}$ & Van Keymeulen (1993) \\
& $\%$ \\
\hline West Flanders & 98 & 88 \\
Antwerp & 91 & 62 \\
East Flanders & 86 & 50 \\
Limburg & 84 & 40 \\
Flemish Brabant & 72 & 48 \\
\hline
\end{tabular}

In some parts of the eastern province of Limburg, bordering on Dutch Limburg, the dialect has changed far more dramatically than in the other provinces (Vandekerckhove (2009: 84-86)). An important factor is the industrialization by the establishment of coal mines and related (im)migration in these areas, similar to the southeastern part of Netherlandic Limburg (see also section 4.3. below).

A study by Belemans conducted in 2001 in this area shows both functional and structural loss at the lexical level (cf. Belemans and Keulen 2004: 78-79). Inhabitants of Bilzen were selected randomly and filled in a questionnaire about their dialect use. $70 \%$ of them, i.e. 273 inhabitants (Belemans 2009: 74), returned the questionnaire. Table 20.2 reveals a considerable decrease of the use of dialect across generations from old to young, in particular between the middle $(41.7 \%)$ and the youngest $(11 \%)$ age group:

Tab. 20.2: The use of dialect by inhabitants of Bilzen (random sample) in 2002

\begin{tabular}{lcc}
\hline age & dialect of Bilzen & other dialect \\
\hline $55-85$ & $61 \%$ & $55 \%$ \\
$25-54$ & $41.7 \%$ & $43 \%$ \\
$16-24$ & $11 \%$ & $14 \%$ \\
\hline
\end{tabular}

In the 55-85 age range, the dialect is used more often by women than by men, as Table 20.3 shows. However, between 16 and 54 years, men use the dialect considerably more often than women of this age group. Note that the use of dialect by women between 16 and 24 years old is zero. Belemans and Keulen (2004: 78) and Belemans (2009: 74) do not explain why this is the case.

This functional loss is mirrored by structural loss at the lexical level, as will be described later (see section 4.1.). 
Tab. 20.3: The use of dialect by men and women in Bilzen (random sample) in 2002

\begin{tabular}{lcc}
\hline age & men & women \\
\hline $65-85$ & $48 \%$ & $64 \%$ \\
$55-64$ & $56 \%$ & $69 \%$ \\
$45-54$ & $53 \%$ & $25 \%$ \\
$35-44$ & $46 \%$ & $39 \%$ \\
$25-34$ & $60 \%$ & $23 \%$ \\
$16-24$ & $21 \%$ & $0 \%$ \\
\hline
\end{tabular}

\subsection{Limburg in the Netherlands}

In this section, the four most large-scale recent studies on the reported use and so-called 'domains of dialect use' of Limburg dialects in the Netherlands will be discussed. It is not possible to discuss all studies about the use of the Limburg dialect in various domains in this chapter. See, among others, Boves and Vousten (1996; Netherlandic Limburg), Cornips and Hulk (2006; Heerlen), Extra (2004; Maastricht), Giesbers, Kroon and Liebrand (1978; northern Limburg), Hinskens (1999; Landgraaf), Münstermann (1986; Maastricht), Münstermann and Hagen (1986), Stijnen and Vallen (1989, about the so-called Kerkrade project, cf. also Kroon and Vallen Kroon (eds.) 2004), Voortman (1994; Roermond, specifically about dialect features in the speech of members of the socio-economic upper crust), Vousten, Bongaerts and Knops (1989; Venray). The oldest study is Weijnen (1967). Weijnen collected data from 11,127 pupils in ten primary schools throughout the Dutch province of Limburg and their fathers between 1964 and 1966. His survey provides quantitative information about, among other things, how many children speak the dialect in 'the street' and how many fathers use dialect when speaking to their children and wives at home. The mean use of dialect by children in the public domain ('street') is $84.7 \%$ and ranges from $60 \%$ (Weert; 33,271 inhabitants) to $100 \%$ (Mesch: 360 inhabitants). With a percentage of 26.8, Heerlen is an exception (see section 4.2. for discussion of the exceptional position of Heerlen in Limburg). All locations show roughly the same percentages of dialect use by fathers in the home domain. Heerlen reports a considerable higher percentage of dialect use of fathers in the home domain when they are speaking to their children $(40.1 \%)$ or wives $(50.3 \%)$ than to children in the public domain $(26.8 \%)$. This corresponds to the low percentage of fathers $-66.3 \%$ - who are born in Heerlen or in Limburg versus $80.3 \%$ in Maastricht (94,985 inhabitants).

A large-scale study by Driessen (2006) analysed developments in the reported use of the dialect versus the standard variety from 1995 to 2003 throughout the Netherlands. He contacted 600 Dutch primary schools involving 34,240 pupils and their parents, using data from five measurement points of the national cohort study Primary Education (PRIMA). His study shows that participants in Limburg report the highest use of dialect between parents in the Netherlands from 1995 onwards (63 percent). Table 20.4 presents the different percentages for the use of dialect according to different role-relations in the home domain in Limburg and the Netherlands. It is the parents within the home domain who use dialect most frequently. Note that the percentages in the home domain are considerably lower than in Weijnen's study of 30 years earlier, although both surveys questioned children and parents in a school context: 
Tab. 20.4: Dialect use in the home domain in Limburg and the Netherlands from 1995 until 2003 (in \%)

\begin{tabular}{llccccc}
\hline & Role relations & 1995 & 1997 & 1999 & 2001 & 2003 \\
\hline Limburg & mother-father & 63 & 65 & 66 & 64 & 57 \\
& child-mother & 50 & 53 & 55 & 49 & 46 \\
& child-father & 51 & 54 & 56 & 50 & 46 \\
& child-siblings & 50 & 54 & 54 & 51 & 47 \\
& child-friends & 42 & 42 & 50 & 40 & 39 \\
& mother-father & 27 & 22 & 20 & 18 & 18 \\
& child-mother & 13 & 12 & 10 & 8 & 8 \\
& child-father & 14 & 12 & 10 & 9 & 8 \\
& child-siblings & 13 & 12 & 10 & 9 & 8 \\
& child-friends & 12 & 9 & 9 & 7 & 7 \\
\hline
\end{tabular}

According to Driessen, parents in Limburg with higher levels of education use the dialect as well (cf. 2006: 109). He also investigated the relation between speaking a dialect and general language proficiency by means of the results of the primary school children on standardized comprehension tasks administered in all Dutch primary schools (see www.cito.com). Children speaking a Limburg dialect show the highest command of SD (Driessen 2006: 109).

Third, Goeman and Jongenburger (2009) report on a survey in 1998 that was carried out by the National Census Bureau (CBS) in the Netherlands. The questions were part of a questionnaire module of Permanent Onderzoek Leefsituatie 'Longitudinal survey of living conditions', a yearly survey investigating the population's way of life and the social climate in the Netherlands. A representative sample of people were surveyed, for the first time in history, about domains of dialect use, the use of dialect, the use of a variety between dialect and the standard language, and on attitudes toward the wane of dialects. In the Netherlands, half of the population claims to speak a dialect sometimes $(52 \%)$. There is no information about the meaning of the term 'dialect' as understood by the subjects who answered the questionnaire (see also section 2.1.). The reported use of dialect is higher in the home domain than in the public domain. The same number of people $(51 \%)$ claim to speak dialect to their children, with somewhat higher percentages found when speaking with friends or neighbours (around $54 \%$ ). Dialect use is considerably more frequent with mother, father, and partner $(67 \%, 64 \%, 62 \%$, respectively) but is less frequent with colleagues at work who themselves speak a dialect $(40 \%)$ and considerably less frequent with one's doctor or dentist or with strangers $(24 \%$ and $22 \%$, respectively). A large part of the respondents regrets the decline of the dialects $(70 \%)$, even if they themselves report not speaking a dialect. Goeman and Jongenburger (2009: 46) argue that these decreasing percentages of reported dialect use correspond to distinct, but partly overlapping, chronological socialization phases during one's lifetime: (i) childhood socialization in one's family and the mental imprints that are left from that stage; (ii) when people are socialized outside the family and are giving form to their life course on their own, making friends, searching for partners, starting their own family; (iii) contact with people who are at a greater distance from family and friends, such as one's doctor, dentist or strangers. 
The sizeable study of Goeman and Jongenburger (2009) reports on three different areas in the Dutch province of Limburg, namely the northern, middle and southern regions. The percentages of dialect use are among the highest in the middle and north of Limburg. The percentage of subjects who claim to speak dialect sometimes is $80 \%$ to $100 \%$ for the northern and middle part of Limburg, and $60 \%$ to $80 \%$ for the southern area (Goeman and Jongenburger 2009: 33-36). The lower percentages in the southern part of Limburg reflect the industrial developments in Heerlen and the former coalmining area and related (im)migration (section 4.2., cf. Cornips 1994, Goeman and Jongenburger 2009: 38). Also in Limburg, the reported use of dialect decreases from the socialization phases during the life phases (i) to (iii), as described above. The percentage of speakers who claim to use a regional (intermediate) variety sometimes (cf. Auer 2005, Cornips 1994, 2006), that is to say, a variety that sometimes converges more to the standard variety, with only regional grammatical including phonological characteristics being retained, sometimes stripped only of very specific local features, is zero in north and middle Limburg. As many as a fourth to half of the subjects in the south report using such a regional variety.

Goeman and Jongenburger (2009) summarize the findings of the CBS study as follows. First, the strongest positive effect on dialect use comes from having a positive attitude to the existence of dialects, i.e. by regretting their decline. Second, decreasing percentages of reported dialect use reflect the effects from three socialization phases: from childhood socialization in one's family and socialization outside the family through contact with people who are at a greater distance from family. Fourth, less urbanized speakers tend to use more dialect. Finally, women disprefer dialect speaking compared to men.

The last study in this respect is Belemans (2002). He analysed the use of dialect, attitudes and opinions about the local dialect in Limburg, working under commission of the "Raod veur 't Limburgs" (Council for Limburgian) in 2001-2002. A questionnaire was placed on the website of the Dutch province of Limburg which was completed by 1,599 subjects (see < http://www.limburg.nl $>$ ). Subjects who were between 30 and 60 years old with a high level of education and living in or originating from mid-Limburg were overrepresented. $83 \%$ of the subjects were able to speak the dialect of their village whereas $66 \%$ reported to speak another dialect than that of their village as well. Over $80 \%$ of the subjects claimed to speak dialect with other speakers of the dialect of the village and with parents, friends, hairdresser, butcher, and people living in their own street and with strangers when asking for directions in the local dialect. Due to mixed marriages, Belemans suggests, the dialect is used less often $(60 \%-80 \%)$ in most intimate communication situations and conversations with partner and children, with the partner at home, with partner if there are strangers around and with children. The dialect is used less than $60 \%$ at school and work $(55 \%)$, with the doctor $(40 \%)$ and to a stranger on the phone $(20 \%)$.

In conclusion, all attitudinal studies discussed above reveal that the dialect is omnipresent in Netherlandic Limburg. However, the percentages decrease through time if we compare the school children in 1966 (Weijnen 1967) to 1995-2003 (Driessen 2006). Moreover, the percentages differ considerably depending who is involved in which role; that is, pupils and their parents interviewed in a school context reveal lower percentages of dialect use (Driessen 2006) than subjects who were interviewed using a general questionnaire (Goeman and Jongenburger 2009). Data for subjects at the national level (Goe- 
man and Jongenburger 2009) reveal lower percentages of dialect use than voluntary, selfrecruited subjects interested in local, Limburgian issues (Belemans 2002). Finally, it is hard to compare the results of the surveys unambiguously since the methodology, types of questions, role relations (i.e. being a parent or a self-recruited interested subject), and interpretation of the results may differ considerably.

\subsection{Desiderata}

In all studies about language use, 'place' is considered to correlate importantly (and often in a static way) with linguistic variation. Places such as 'Limburg', 'Maastricht', 'Bilzen', (school in a) 'neighbourhood', 'region' have been implicitly conceived of in objective, physical terms and, as such, as unproblematic concepts. However, Johnstone (2004: 66) points out that such categories may not correlate with demographic facts in simple ways. It also depends on whether and how people define themselves as 'being from Limburg' and/or 'being from Heerlen' i.e. 'place' might also be a culturally defined category. From this perspective, speakers may also be seen as constructing place as they experience physical and social space, and different speakers may orient to place in very different ways and for very different purposes with different linguistic orientations (Cornips, de Rooij and Stengs 2012, Johnstone 2004: 66). Thus, within Flanders the 'Limburg' area may show the lowest dialect vitality whereas the 'Limburg' area in the Netherlands shows the highest vitality at the Dutch national level.

Moreover, the meaning of the word 'dialect' is context- and use-dependent. Goeman and Jongenburger (2009: 33) note that "the perception of what constitutes a dialect, the concept or mental idea of dialect may not be the same for everybody". In their data, for instance, women show larger fluctuations around the mean dialect use at every educational level, a pattern that, according to the authors, might indicate that women have a concept of dialect that differs from that of men. Belemans (2002), in his analysis of the results of his web questionnaire, observes that older people may have a different idea of which varieties count as 'dialect' than younger people. According to Belemans, the older people in this study define the term 'dialect' in a static way and bound to their generation, implying that their generation is the only one that speaks dialect properly. The youngest generation, however, considers 'dialect' as a dynamic entity and they claim that their variety, although different from their grandparents', is still a dialect. Blommaert (2010: 382) argues that a dialect or regional variety is traditionally seen as something that anchors people in a local context: it is described as something that belongs to a particular environment. But nowadays language is also a tool for mobility, hence, it is also something translocal, since it moves along with people across space and time, and it is being deployed locally in ways that reveal the translocal histories of the speaker's resources. In this perspective, the connection between a speech community and a set of established, and shared, forms of knowledge of languages and language norms must be questioned. What is more, the same language form may have very different functions, depending on where, how and why it is used, and how it fits into speakers' repertoires. This functional relativity is of crucial importance for understanding processes of mobility and language; that is, what works well in one place may not work at all elsewhere and highly articulate people in one place may be very inarticulate in other places. Also in 
Limburg, as elsewhere, people move. As Blommaert (2010: 368) points out, the movement of people across space is a move across spaces filled with norms, expectations, conceptions of what counts as proper and normal language use and what does not. Therefore, the functional relativity of the term 'dialect' shows that it is important for the analysis and interpretation of the results to include an insider's understanding. By means of classic ethnographic methods for data collection as participant observation, interviewing, social network analysis, and (self-) recordings, such qualitative research informs us in-depth on linguistic practices of speaking dialect, for example, between family members, within school as well as in wider society. This type of research also informs us about the question which specific language ideologies in the home, public domain, school determine the language choice between standard, dialect and/or hybrid variety.

\section{Horizontal dialect convergences/divergences under the influence of political borders}

\subsection{Phonological and morphological variants}

Gerritsen (1999) investigated the convergence and divergence of dialects in three dialects that were said to be linguistically identical until the mid-twentieth century (the dialects spoken in Maaseik in Belgian Limburg, Susteren in Netherlandic Limburg and Waldfeucht in neighbouring Germany). The aim of her survey was to examine if and how these dialects have changed under the influence of two recent national borders (The Netherlands - Belgium - Germany) and, consequently, of two different standard languages spoken in three different nations (Dutch and standard German). Maaseik (B) and Susteren (NL) are six kilometres apart and Susteren and Waldfeucht (G) are too. The linguistic variables examined were phonological, morphological, and lexical. Examples from Gerritsen (1992: 49) are provided in (3-5):

(3) old dialect of

Maaseik (B)

Waldfeucht (G)

Susteren (NL)
SD Dutch in the Netherlands
SD Dutch

$$
\text { in Belgium }
$$

Standard

German [k]

[sx]

neusje

[na.s]

plural [k]

[sx] [x] 'also', 'I'

[ ] 'sheep'

(4) diminutive

\begin{tabular}{|c|c|c|c|c|}
\hline [nesk $k$ ] & neusje & neusje & Näschen & 'nose-DIM' \\
\hline $\begin{array}{l}{[\mathrm{na} . \mathrm{s}]} \\
\text { plural }\end{array}$ & & & & 'nose' \\
\hline [by.k] (sing. [bu.k]) & buiken & buiken & Bäuche & 'stomachs' \\
\hline
\end{tabular}

(5) boks

broek

broek

Hose

'trousers' 
Two age groups were selected in the three locations $(n=16$ per location): girls aged 14 to 16 years $(n=24)$ and women aged 35 to 50 years $(n=24)$. The linguistic variants were elicited by means of oral interviews. At the lexical level, the girls used less dialect (range $24 \%-65 \%$ ) or more standard variants than the women (dialect range $60 \%-$ $87 \%$ ). The locations show different patterns: for instance, the Waldfeucht speakers in Germany use fewer dialect variants than those from Maaseik in Belgium and Susteren in the Netherlands. It appears that lexical items that occur relatively frequently undergo less lexical standardization than less frequently used ones (Gerritsen 1999: 52). At the phonological level, women and girls hardly differ from each other in Susteren $(96 \%$ and $100 \%$, respectively) and Maaseik ( $83 \%$ and $86 \%$, respectively) but they do in Waldfeucht (66\% and 19\%, respectively). Again, speakers from Waldfeucht use far fewer dialect forms than those from Maaseik and Susteren. At the morphological level (diminutive and plural formation), women do not differ among the three places (dialect forms $96 \%, 93 \%$ and $89 \%$ ) but women and girls differ in the use of dialect forms in Maaseik $(96 \%$ and $64 \%$, respectively), in Susteren ( $93 \%$ and $75 \%$, respectively) and, dramatically, in Waldfeucht ( $89 \%$ and $7 \%$, respectively). The girls in Waldfeucht, in particular, showed a dramatic decrease in the use of dialect variants.

At the phonological and lexical level, the subjects produced either standard or dialect forms. However, at the morphological level mixed variants also emerged. The girls in Waldfeucht, for instance, produced $63 \%$ standard variants and $27 \%$ so-called hyperdialectisms: variants that occur neither in the standard nor in the dialect but can be considered an attempt to create a dialect form. An example is diminutive [hancə] 'hand dim.' whereas [hencə] is the dialect form and händchen is standard German. In addition to hyperdialectisms, Gerritsen (1999: 54) also distinguishes (i) partial adaptations to the standard language, for example, plural formation with both an umlaut and the addition of the suffix -[ə], e.g. [høtə] 'hats', in Maaseik whereas the dialect variant is sg. [ho.t] 'hat' versus pl. [høt] 'hats', (ii) hypercorrections consisting of forms with morphological elements that occur neither in the dialect nor in the standard but that could be considered an attempt to create a form of the standard language. The only example is [ $\int$ tato] 'cities' in Maaseik and Susteren (dialectal plural [ $\int$ tej] and standard plural [ste.də]). Girls in Waldfeucht use the largest number of mixed forms most affected by the standard language (30\% of the responses), followed by Susteren (12\%) and Maaseik (5\%). Partial adaptations to the standard and hypercorrections occur especially in the language of Maaseik and Susteren girls, and hyperdialectisms occur especially in the language of Waldfeucht girls. According to Gerritsen (1999: 55), the use of mixed forms indicates a rather weak knowledge of the dialect. Since the use of mixed and standard forms takes place in the youngest generation, Gerritsen concludes that the political border between the Netherlands and Germany has led to a dialect boundary, resulting in a sharp separation of the dialects there, whereas this is hardly the case for the border between Belgium and the Netherlands. With respect to the latter issue, Cajot $(1977,1983)$ presents the same conclusion for the lexical level.

However, the question arises whether the changes in Waldfeucht, i.e. the increased use of mixed forms by the youngest speakers, are due to a change of verbal repertoire. This study shows, in particular for the morphological level, that dialect levelling does not necessarily amount to convergence to the standard language since new (intermediate) variants may emerge (cf. also section 3.2.; Hinskens 1992; Cornips 2006). 


\subsection{Syntactic variants}

In 1885, an extensive questionnaire by the linguist Willems was distributed throughout the Dutch-speaking regions of Belgium and the southern part of the Netherlands, including the provinces of Limburg, and the surrounding Rhineland area in Germany (cf. Goossens 1989). The total number of localities and villages in the provinces of Limburg and Rhineland was 121. In this questionnaire, local dialect speakers were offered a choice of adjunct middles, as illustrated in (6), and were asked to 'translate' the standard constructions into their local vernacular (Cornips 1996, Cornips and Corrigan 2005):

(6) SD Dit bed slaapt goed

this bed sleeps well

'This bed is comfortable'

The responses in Limburg reveal that an adjunct middle like in (6) was ungrammatical in 1885. Instead of exact translations of the sentence in (6), subjects provide other types of middles in the dialect, especially the counterparts in (6) combined with the $3 \mathrm{sg}$ (and $3 \mathrm{pl}$, for that matter) reflexive marker zich (Cornips 1996). Figure 20.1 presents the geographical distribution of the three types of middle constructions construed with the reflexive zich in 1885. This shows that the Rhineland area allows all types of adjunct middles with a reflexive, the northern part of Limburg allows two out of three types with a reflexive, and the south of Limburg allows only one type of middle with a reflexive. Examples of an impersonal middle, an adjunct middle and an instrumental middle, respectively, are presented in (7):

(7) a. NL Posterholt In dej zaal zingt 't zich goed

in this hall sings it refl well

b. Fl Zoutleeuw Deë zoal zingt gemäkkelek

this hall sings easily

c. $G$ Düsseldorf Di Tint shrifft zich jot

this ink writes refl well

\begin{tabular}{lcccc}
\hline 1885 & south of Limburg & north of Limburg & Rhineland \\
\hline impersonal middle & $+\underline{\text { zich }}$ & $\sqrt{ }$ & $\sqrt{ }$ & $\sqrt{ }$ \\
adjunct middle & $+\underline{\text { zich }}$ & $*$ & $\sqrt{ }$ & $\sqrt{ }$ \\
instrumental middle $+\underline{\text { zich }}$ & $*$ & $*$ & $\sqrt{ }$ \\
\hline
\end{tabular}

Fig. 20.1: Distribution of the Instrumental, Adjunct and Impersonal Middles in 1885

Questions of the same type were repeated in the Meertens and Rheinische Landeskunde questionnaire in 1994. The linguistic situation more than a hundred years later is very interesting. With respect to Limburg, the responses show that dialects converged horizontally, that is, they now all allow the three types of middles and they all allow the reflexive marker zich (see also SAND, vol. I 2005: 77). Importantly, the dialects diverged from SD: 


\begin{tabular}{lcccc}
\hline & $\begin{array}{c}\text { south of } \\
\text { Limburg 1885 }\end{array}$ & $\begin{array}{c}\text { north of } \\
\text { Limburg 1885 }\end{array}$ & $\begin{array}{c}\text { Limburg } \\
1994\end{array}$ & $\begin{array}{c}\text { SD } \\
1994\end{array}$ \\
\hline reflexive impersonal & $\sqrt{ }$ & $\sqrt{ }$ & $\sqrt{ }$ & $*$ \\
reflexive adjunct & $*$ & $\sqrt{ }$ & $\sqrt{ }$ & $*$ \\
reflexive instrumental & $*$ & $*$ & $\sqrt{ }$ & $*$ \\
\hline
\end{tabular}

Fig. 20.2: Dialects in Limburg and SD between 1885-1994 on the basis of the Willems and Meertens questionnaires in 1885 and 1994, respectively

With respect to the surrounding German dialects in the Rhineland, the responses show that, in contrast to Limburg, the Rhineland dialects and standard German have converged:

\begin{tabular}{lccc}
\hline & Rhineland & Rhineland & Standard German \\
& 1885 & 1994 & 1994 \\
\hline reflexive impersonal & $\sqrt{ }$ & $\sqrt{ }$ & $\sqrt{ }$ \\
reflexive adjunct & $\sqrt{ }$ & $*$ & $*$ \\
reflexive instrumental & $\sqrt{ }$ & $*$ & $*$ \\
\hline
\end{tabular}

Fig. 20.3: Rhineland dialects and standard German between 1885-1995 on the basis of the Willems and Meertens questionnaires in 1885 and 1994, respectively

This study shows that dialect levelling may or may not boil down to convergence to the standard variety also at the syntactic level, as illustrated by the Rhineland and Limburg dialects, respectively. It also reveals that, nowadays, the political border between Limburg in the Netherlands and Germany has become a linguistic boundary (Cornips and Corrigan 2005; cf. also Hinskens 1997).

\section{Dialect convergences/divergences according to the extent of geographical distribution}

One of the hypotheses examined by Hinskens (1992) is that dialect levelling is a twodimensional process in that it affects variation on the dialect-standard language dimension as well as variation across dialects. He selected 20 phonological, morphological and morphosyntactic variants from the Rimburg dialect in southeastern Limburg (belonging to the Ripuarian group of dialects), ranging in areal distribution from restricted (characteristic for the Ripuarian dialects) to wide (Ripuarian, transition and East-Limburgian dialects; Hinskens 1992: 108-112). Examples are provided in (8) through (11), respectively:

(8) Ripuarian

a. $\gamma$-weakening

$\begin{array}{lll}\text { gas } & \text { ja.s } & \text { 'gas' } \\ \text { glas } & \text { jla.s } & \text { 'glass' }\end{array}$


b. [s] in diminutive allomorph following velar-final stems tang-etje teng[s]ke 'little (pair of) tweezers'

(9) transition zone

a. R-deletion soort $\quad \mathrm{so}\left[\mathrm{i}^{\circ}\right] \mathrm{t}$ 'sort'

b. derivational suffix einde-lijk entlI[ç] 'finally'

(10) East-Limburg

a. word-final [t]-deletion echt $\quad$ ç real(ly)

b. expletive er is nog soep [ət] is nog soep 'there is still some soup left'

He selected 27 subjects divided into three age groups and collected data through sociolinguistic interviews, elicitation tasks and in- and out-group conversations. In general, the process of dialect levelling was strongest in the variants with the narrowest areal spread (cf. (8)), and weakest in those with the widest areal spread (cf. (10)) (Hinskens 1992: 462). Although 4 out of 14 dialect features were found to be subject to processes of levelling, the result of this process does not necessarily imply convergence towards the standard language. Instead, they converged towards Limburg dialects with the widest areal spread. The morphological variants also underwent levelling, whereas dialect characteristics such as umlaut and tone contrasts remained intact.

\section{Vertical convergences: Dialect - standard in (apparent) time}

\subsection{Lexicon}

Belemans (cf. Belemans and Keulen 2004: 86) studied the use of lexical dialect variants in about ten locations in Belgian Limburg; each location was represented by 60 dialect speakers. Traditional dialect words like $u i$ 'onion' were translated into the dialect in $60 \%$ of the cases whereas dialect translations for words like prikkeldraad 'barbed wire' amounted only to up to $5 \%$. The results of this study show the following trends with respect to convergence to SD at the lexical level. First, there is more loss in villages that function as regional centres such as Hasselt, Bilzen, Maaseik than in smaller, rural locations like Kanne, Stokkem or Borgloon. Second, dialects spoken at the periphery of the Limburg area are more vulnerable than dialects in the centre. Finally, there is less loss in areas where the grid of the locations is very dense (such as the southern part of Limburg) than where the grid is open (such as the northern part). However, certain lexical dialect variants survive in the standard language, for example words as krevat 'necktie' and bot 'boot'. 


\subsection{Phonology}

Some of Gerritsen's (1999) findings, discussed in section 3.1. above, are relevant with regard to vertical phonological convergence.

In his study of processes of dialect levelling, Hinskens (1992) compared dialect features in different language components and with different degrees of geographical spread (cf. section 4 above). The apparent time levelling which was established for features with a strictly local or very limited regional distribution was sometimes a matter of crossdialectal convergence ('koineisation'), while that of features with a pan-Limburg distribution typically showed dialect-standard convergence. The phonological dialect phenomena with the widest areal spread studied were word-final [t]-deletion and sandhi voicing. The author established that both phenomena are strongly resistant to change. While the overall levels of word-final [t]-deletion show an apparent time increase, the use of sandhi voicing was already next to categorical in the oldest generations and did not undergo any apparent time loss. Especially sandhi voicing occurs in the regional variety of the standard language to such an extent that it can be regarded as an indicator for Limburgian.

\subsection{Syntax: Definite articles and double object constructions in the dialect}

Bakkes (1996) examined the social distribution of syntactic variants in the local dialect of the village of Montfort in middle Limburg. He selected 37 male and female subjects divided into three age groups: old (aged 61 to 88 years), middle (aged 44 to 56 years) and young (aged 17 to 28 years). The subjects mostly belonged to the same family, e.g. grandmother - mother - grandchild. The dialect data were collected by means of sociolinguistic interviews. One of the Limburg syntactic variants that is ungrammatical in SD is the so-called dative inalienable possession construction, in which the referent of the dative object (the dative object being the reflexive pronoun zich) is the possessor of the inalienable body part(s) denoted by the direct object, as illustrated in (11) (see Bakkes 1996: 172). This type of construction with a reflexive pronoun is grammatical in the eastern Dutch dialects from north to south, with the exception of Groningen (SAND, vol. I: 79, cf. Barbiers et al. 2005). The DP referring to body part(s) such as handen 'hands' is headed by the definite determiner de 'the' (Broekhuis and Cornips 1994, Cornips 1994).

(11) hea hat zich de heng gewesche.

he has refl the hands washed

'He is washing his hands'

The so-called benefactive construction is grammatical in the local dialects but ungrammatical in SD. The double object construction in (12) denotes a state of affairs that can be described as the end-point of the action (Cornips 1998, Cornips and Hulk 1996):

(12) a. Zij wast hem/zich de auto.

She washes him/refl the car

'She is washing the car for him/for herself.' 
b. Zij verft hem/zich. het huis.

She paints him/refl the house

'She is painting the house for him(self).'

Bakkes examined both types of constructions and found that both are less frequently produced by the younger than the older generations (Bakkes 1996: 183). Note that the percentages in Table 20.5 have been calculated on tokens divided by the total number of words since Bakkes does not provide information about the potential occurrences, i.e. non-occurrences of the double object constructions in the variable environment (Labov et al. 1968: 70)

Tab. 20.5: The use of double object constructions (15) and (16) in the dialect of Montfort

\begin{tabular}{lcrrrr}
\hline Bakkes (1996: 183) & \#words & $\begin{array}{c}\text { inalienable } \\
\text { possession }\end{array}$ & benefactive \\
\hline Old & 30,682 & 24 & $62 \%$ & 93 & $53 \%$ \\
Middle & 72,686 & 11 & $28 \%$ & 72 & $41 \%$ \\
Young & 91,305 & 4 & $10 \%$ & 11 & $6 \%$ \\
\hline
\end{tabular}

Bakkes concludes that local dialect constructions that are not supported by SD - since they are non-existent and ungrammatical in that variety - are disappearing in the youngest generations. In this respect, the local dialect and SD are converging through time.

\subsection{Syntax: Double object constructions in the regional standard variety}

The study of the social distribution of syntactic variation in Heerlen Dutch is the only one that examines the influence of the local dialect on the standard variety in the Limburg dialect area (Cornips 1994). Heerlen is a unique case for such a study since, in comparison with other Dutch dialect areas, it occupies an exceptional position in Limburg and the Netherlands. In the years between 1899 and 1930, the expanding mining industry in this area attracted numerous workers from elsewhere in the Netherlands and abroad, leaving a distinctive mark on the language used in this area.

When we carefully examine the varieties of Dutch in Heerlen, it is obvious that what distinguishes Heerlen Dutch from SD is that in the former (i) double objects appear in a much wider range of constructions and (ii) the reflexive zich has a wider set of uses (cf. Cornips 1994). Nowadays, Heerlen has about 90,000 inhabitants and there is still a large spectrum of intermediate lects varying between the local dialect and SD.

Cornips $(1994,1998)$ studied a random sample of 67 male speakers, in which three speaker variables were taken into account: language background, level of education/ occupation and age. The data consist of 33.5 hours of recorded spontaneous speech between two speakers who did not know each other but belonged to the same cell with respect to the independent variables mentioned above (in-group conversation). The recordings took place at the speakers' homes. For Heerlen Dutch, we will consider the same double object constructions as in Bakkes' study (section 4.1.), i.e. the inalienable possession and benefactive construction. The study by Cornips shows that these double object constructions are also present in the standard variety in Heerlen i.e. in Heerlen 
Dutch. Table 20.6 shows the numbers of speakers using the benefactive and inalienable possession construction in spontaneous speech. In contrast to Bakkes, younger and older speakers do not differ significantly in the use of the benefactive constructions. However, what is very interesting is that the use of the dative inalienable possession construction increases significantly from young to old in a standard variety. In this respect, the standard variety in Heerlen and SD are diverging in time even though the double object constructions are ungrammatical in SD.

Tab. 20.6: The use of the benefactive and inalienable construction in Heerlen SD (Cornips 1994)

\begin{tabular}{|c|c|c|c|c|}
\hline & \multicolumn{2}{|c|}{$\begin{array}{c}\text { old } \\
(>60 \text { years })\end{array}$} & \multicolumn{2}{|c|}{$\begin{array}{c}\text { young } \\
(20-45 \text { years })\end{array}$} \\
\hline & abs. & $\%$ & abs. & $\%$ \\
\hline * \#speakers producing benefactive & $22 / 30$ & 73 & $20 / 37$ & 54 \\
\hline ** \#speakers producing inalienable possession & $9 / 30$ & 30 & $20 / 37$ & 54 \\
\hline
\end{tabular}

\subsection{Code-switching between dialect and standard}

Code-switching between dialect and SD constitutes a case of situational vertical convergence. Giesbers (1989: 333-341) examined code-switching in Ottersum, a small village located in the northern part of Limburg. He collected data by way of participant observation and recorded about 30 hours of spontaneous speech in the domestic circle. According to Giesbers (1989: 334), the Ottersum dialect has lost considerable ground to the standard language over a relatively short period of time, especially in primary socialization. Children are addressed in the standard language as the unmarked code, even if the parents use dialect among themselves. The standard language has developed from a variety used exclusively for 'secondary relations' and a symbol of distance to a variety which also plays a part in primary and intimate relations, even informally between adults. Giesbers argues that despite these facts the use of dialect remains important, especially because of the positive attitudes towards the dialect, even among nonnative speaking children and youths. The data reveal 5,515 switches between dialect and standard language, consisting of 50.2\% language alternations, $40.9 \%$ insertions (i.e. one word-switches) and 9\% intermediate forms. Intermediate forms are forms that cannot be unambiguously assigned to the dialect or SD. Sentence (13) presents the intermediate form bəyRafənIs 'funeral' for SD begrafenis or dialect bəyRafįnIs (dialect in bold, intermediate form in italics):

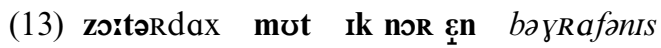

(Giesbers 1989: 97) saturday must I to a funeral

An example of intrasentential code-switching is presented in (18):

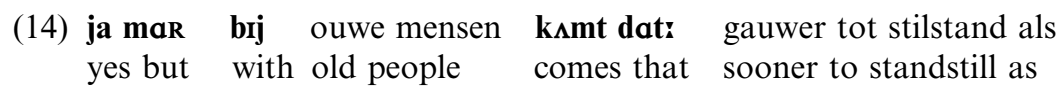


brj jưə minsə wa

with young people he

(Giesbers 1989: 147)

'yes but older people come to a standstill sooner than young people'

Code-switching is not related to a lack of competence in SD, witness the fact that the predominant switch direction is from dialect towards the standard variety. The most frequent extra-linguistic categories for code-switching are adaptation to the (language proficiency and/or preference of the) addressee by the dialect speaker, and contextual code-switching (Giesbers 1989: 337).

\subsection{Conclusion}

The studies mentioned above all show that processes of linguistic convergence and divergence are complex. Dialects may converge around political borders, as is the case with the Dutch-Belgian border, where people on both sides speak Dutch as the standard variety (cf. Gerritsen 1999; Cornips and Corrigan 2005). In the process of convergence, dialects may in fact at the same time converge to or diverge from the standard variety, as is the case with the Rhineland and Limburg dialects around the Dutch-German border (Hinskens 1992; Cornips and Corrigan 2005). Speakers of dialects may retain their specific local features and in doing so diverge from other surrounding dialects, or speakers may strip away local dialect features in favour of those with a wider areal distribution and in doing so converge with other dialects (Hinskens 1992). A local dialect may converge to the standard variety by losing specific dialect characteristics through time (Bakkes 1996), whereas an emerging regional standard variety may diverge from SD in absorbing just these local dialect characteristics in the speech of young people (Cornips 1994, Vandekerckhove 2009). Code-switching and the use of intermediate forms between SD and a dialect form an example of vertical levelling (Giesbers 1989).

The linguistic results of language contact between dialects and immigrant languages such as Turkish and Moroccan-Arabic have not been studied (in detail) yet.

The studies above show that the mutual influence of various language varieties in Limburg are quite manifold. When we describe the linguistic situation in Limburg it is therefore problematic to portray a dialect or any other variety as existing in isolation and as a bound entity. It is not possible for a given community to exclusively lay claim to a given variety (let alone a homogeneous variety) on the basis of the linguistic facts alone. All recent developments in Limburg show that dialects do not converge unambiguously towards the standard but that a range of 'intermediate' varieties between and within individual speakers arise, depending on social and discourse contexts.

\section{Desiderata}

Linguistically, Limburg is not a homogenous entity but an administrative, political unit. The varieties spoken in Limburg are fluid entities, which cannot be distinguished neatly from other varieties. According to Eckert (2004), our focus on speech communities has led to the view that the borders of communities are boundaries - cut-off points between 
two places where different things happen, rather than a transitional place. Crucially, although members of a population defined as living in the same community may all agree that they live in a particular area or political unit, they do not orient in a homogenous way to that area or unit or its surroundings. Different people in a given community will view the boundaries differently, use different parts of the community, and participate in the surroundings differently. According to Eckert (2004 and 2011), these differences will result in different patterns of contact, which have implications for linguistic influence. Thus, although, the varieties spoken in Limburg are genetically related (with the exception of the immigrant languages) and share almost all of their grammar, they are perceived as different language varieties by their speakers and may be associated with different identities and vice versa. Subsequently, the practices of language use and the use of certain linguistic features in social interaction will serve as indicators of the interlocutors' social standing and identity (cf. Cornips, de Rooij and Stengs 2012). At that point, the linguistic form becomes a marker (Eckert 2008, Labov 1972). On the one hand, being from Limburg may be considered as a potential determinant of language variation, i.e. local features may be a (conscious or subconsciously) reflection of the origin of the speaker. On the other, speakers may have distinctive ways of speaking, which emerge out of shared social practices, in interaction with each other. These social practices may give rise to a local and constructed "Limburgian" identity, rather than an expressed one (Eckert 2009). Both processes, i.e. the reflection of and the construction of 'place', should be examined in dialectal and sociolinguistic research (Johnstone 2004), both by sociolinguistic interviews, recording informal conversations, and by ethnographic fieldwork (participant observation), respectively.

\section{Atlases}

FAND $\cdot$ MAND $\cdot$ SAND

\section{References}

Absillis, Kevin, Jürgen Jaspers \& Sarah Van Hoof

2012 De manke usurpator: over Verkavelingsvlaams. Gent: Academia Press.

Auer, Peter

2004 Non-standard evidence in syntactic typology - Methodological remarks on the use of dialect data vs spoken language data. In: Bernd Kortmann (ed.), Dialectology meets typology. Dialect grammar from a cross-linguistic perspective, 69-92. Berlin: Mouton de Gruyter.

Auer, Peter

2005 Europe's sociolinguistic unity, or: A typology of European dialect/standard constellations. In: Nicole Delbecque, Johan van der Auwera and Dirk Geeraerts (eds.), Perspectives on variation, 7-44. Berlin: Mouton de Gruyter.

Bakkes, Pierre

1996 Variatie en verandering in het Montforts. Taalstructurele en sociolinguistische aspecten van een veranderend dorpsdialect. Amsterdam: P. J. Meertens-Instituut.

Belemans, Rob

2002 Eindrapport over de Limburg-enquête. Leuven: KU Leuven. 
Belemans, Rob and Ronny Keulen

2004 Belgisch-Limburgs. Taal in stad en land. Tielt: Lannoo.

Belemans, Rob

2009 Taal of tongval?: de gespleten Limburgse kus, oraal erfgoed en taalpolitiek. Brussels: Pharo.

Blommaert, Jan

2010 The sociolinguistics of globalization. Cambridge: Cambridge University Press.

Blommaert, Jan

2011 Supervernaculars and their dialects. Tilburg Papers in Culture Studies 9.

Boves, Tom and Rob Vousten

1996 Thuistaal en schoolresultaten. In: Roeland van Hout and Joep Kruijssen (eds.), Taalvariaties. Toonzettingen en modulaties op een thema, 23-28. Dordrecht: Foris.

Brassé, Paul and Willem van Schelven

1980 Assilimilatie van vooroorlogse immigranten, drie generaties Polen Slovenen Italianen in Heerlen. The Hague: Staatsuitgeverij.

Broekhuis, Hans and Leonie Cornips

1994 Undative constructions. Linguistics 32(2): 173-189.

Broekhuis, Hans and Leonie Cornips 2012

2012 The verb krijgen 'to get' as an undative verb. Linguistics, 50(6), 1205-1249.

Cajot, José

1977 De rijksgrens tussen beide Limburgen als taalgrens. Taal en Tongval 29: 37-49.

Cajot, José

1983 Nieuwe taalgrensvorming aan de oostgrens. In: hoeverre is de Nederlands-Duitse staatsgrens tot taalgrens aan het evolueren? Jan Segers (ed.), Taalgrensvorming in Zuid-Limburg, 26-43. Hasselt: Mededelingen van de Vereniging voor Limburgse Dialect- en Naamkunde 26.

Cornips, Leonie

1994 De syntactische variatie in het Algemeen Nederlands van Heerlen [Syntactic variation in Heerlen Dutch]. Ph.D. thesis, University of Amsterdam.

Cornips, Leonie

1998 Syntactic variation, parameters and their social distribution. Language Variation and Change 10(1): 1-21.

Cornips, Leonie

1996 The spread of the reflexive adjunct middle in the Limburg dialects: 1885-1994. In: Crit Cremers and Marcel den Dikken (eds.), Linguistics in the Netherlands 1996, 49-60. Am-

Cornips, Leonie sterdam: John Benjamins.

2006 Intermediate Syntactic Variants in a Dialect - Standard Speech Repertoire and Relative Acceptability. In: Gisbert Fanselow, Caroline Féry, Matthias Schlesewsky and Ralf Vogel (eds.), Gradience in Grammar. Generative Perspectives, 85-105. Oxford: Oxford University Press.

Cornips, Leonie and Karen Corrigan

2005 Convergence and Divergence in Grammar. In: Peter Auer, Frans Hinskens and Paul Kerswill (eds.), Dialect Change: Convergence and Divergence in European Languages, 96134. Cambridge: Cambridge University Press.

Cornips, Leonie and Aafke Hulk

1996 Ergative reflexives in Heerlen Dutch and French. Studia Linguistica 50(1): 1-21.

Cornips, Leonie and Aafke Hulk

2006 External and internal factors in bilingual and bidialectal language development: Grammatical gender of the Dutch definite determiner. In: Claire Lefebvre, Lydia White and Christine Jourdan (eds.), L2 Acquisition and Creole Genesis. Dialogues, 355-78. Amsterdam: John Benjamins.

Cornips, Leonie and Willy Jongenburger

2001 Het design en de methodologie van het SAND project. Nederlandse Taalkunde 16: $215-232$. 
Cornips, Leonie and Cecilia Poletto

2005 On standardising syntactic elicitation techniques. Part I. Lingua 115(7): 939-957.

Cornips, Leonie, Vincent de Rooij \& Irene Stengs

2012 Carnavalesk taalgebruik en de constructie van lokale identiteiten. Dutch Journal of Applied Linguistics 1(1), 15-40.

Crompvoets, Herman

1987 Dialekt en standaardtaal in Nederlands Limburg. Mededelingen van de Vereniging voor Limburgse dialect- en naamkunde 43: 1-22.

Dieteren, Remigius O. F. M.

1962 De migratie in de mijnstreek 1900-1935. Bijdragen tot de sociale en economische geschiedenis van het zuiden van Nederland (IX). Nijmegen: Centrale Drukkerij.

Driessen, Geert

2006 Ontwikkelingen in het gebruik van streektalen en dialecten in de periode 1995-2003. Toegepaste Taalwetenschap in Artikelen 75: 103-113.

Eckert, Penelope

2004 Variation and a sense of place. In: Carmen Fought (ed.), Sociolinguistic Variation. Critical reflections, 107-118. Oxford: Oxford University Press.

Eckert, Penelope

2011 Who's there? Language and Space in social anthropology and interactional sociolinguistics. In: Peter Auer and Jürgen E. Schmidt (eds.), Language and Space. An international handbook of linguistic variation. Theories and methods, 163-178. Berlin: Mouton de Gruyter.

Extra, Guus

2004 Taal en identiteit. De vitaliteit van minderheidstalen in vergelijkend perspectief. Taal en Tongval. Themanummer 17: 109-134.

Gerritsen, Marinel

1999 Divergences of dialects in a linguistic laboratory near the Belgian-Dutch-German border: Similar dialects under the influence of different standard languages. Language Variation and Change 11: 43-65.

Giesbers, Herman

1989 Code-switching tussen dialect en standaardtaal. Ph.D. thesis, University of Nijmegen/ P. J. Meertens Instituut, Amsterdam.

Giesbers, Herman, Sjaak Kroon and Rudi Liebrand

1978 Een empirisch-sociodialectologisch onderzoek naar de invloed van dialectgebruik op schoolprestaties in het basisonderwijs in Gennep. M.A. thesis, University of Nijmegen.

Goeman, Ton and Willy Jongenburger

2009 Dimensions and determinants of dialect use in the Netherlands at the individual and regional levels at the end of the twentieth century. Dialect death in Europe? International Journal of Sociology of Language 196/197: 31-72.

Goossens, Jan

1989 Pieter Willems en zijn dialectenquête. Taal en Tongval 2: 5-15.

Hagen, Anton

1989 The Netherlands. In: Ulrich Ammon, Klaus Mattheier and Peter Nelde (eds.), Sociolinguistica. vol. 3, 61-74. Tübingen: Max Niemeyer Verlag.

Hagen, Anton and Herman Giesbers

1988 Dutch sociolinguistic studies. International Journal of the Sociology of Language 73: $29-44$.

Hinskens, Frans

1992 [1996] Dialect levelling in Limburg. Structural and sociolinguistic aspects. Ph.D. thesis, University of Nijmegen. [Abridged and revised version under the same title. Tübingen: Niemeyer.]

Hinskens, Frans

1997 De Nederlands-Duitse staatsgrens als belangrijke toekomstige isoglossenbundel. In: Wim de Geest (ed.), Recente studies in de contactlinguïstiek, 65-79. Bonn: Dümmler. 
Hinskens, Frans

1999 Dialect, tweetaligheid en onderwijs. Grensverleggend onderwijs. In: J. Heinrichs (ed.), Grensverleggend onderwijs Eijkhagencollege, 24-35. Landgraaf: Eijkhagencollege.

Johnstone, Barbara

2004 Place, Globalization and Linguistic Variation. In: Carmen Fought (ed.), Sociolinguistic variation, 65-83. Critical Reflections. Oxford: Oxford Press.

Johnstone, Barbara

2012 Indexing the Local. In: Nikolas Coupland (ed.), Handbook of Language and Globalization, 386-405. Oxford: Oxford University Press.

Kessels-Van der Heijde, Marina

2002 Maastricht, Maestricht, Mestreech. De taalverhoudingen tussen Nederlands, Frans en Maastrichts in de negentiende eeuw. Hilversum: Verloren.

Keulen, Ronny, Ton van de Wijngaard, Herman Crompvoets and Frans Walraven (eds.)

2007 Riek van klank. Inleiding in de Limburgse dialecten. Sittard: Veldeke Limburg.

Knops, Uus

1984 Taalattitudes in Vlaanderen en Nederland. Interdisciplinair Tijdschrift voor Taal en Tekstwetenschap 4: 325-353.

Kroon, Sjaak and Ton Vallen (eds.)

2004 Dialect en school in Limburg. Amsterdam: Aksant Academic Publishers.

Labov, William

1994 Principles of linguistic change. Internal factors. Oxford: Blackwell.

Labov, William, Paul Cohen, Clarance Robins and John Lewis

1968 A Study of the Non standard English of Negro and Puerto-Rican Speakers in New York City, (Co-operative Research Report 3288), Vols. I and II. Philadelphia: US Regional Survey.

Leerssen, Joep

2006 De bronnen van het vaderland: Taal, literatuur en de afbakening van Nederland, 18061890. Nijmegen: Vantilt.

Münstermann, Henk

1986 De vitaliteit van het Maastrichts. Resultaten van een onderzoek naar functionele en structurele aspecten van dialectverlies. Taal en Tongval 38(3-4): 109-127.

Münstermann, Henk and Toon Hagen

1986 Functional and structural aspects of dialect loss: a research plan and some first results. In: Bert Weltens, Kees de Bot and Theo van Els (eds.), Language attrition in progress. Studies on language acquisition, 75-95. Dordrecht: Foris.

Münstermann, Henk and Roeland van Hout

1988 Language attitudes and the prediction of dialect use. In: Roeland van Hout and Uus Knops (eds.), Language attitudes in the Dutch language area, 173-188. Dordrecht: Foris.

Singler, John V.

1988 The homogeneity of the substrate as a factor in pidgin/creole genesis. Language 64(1): $27-51$.

Stijnen, Sjef and Ton Vallen

1989 The Kerkrade project: background, main findings and evaluation. In: Jennifer Cheshire, Viv Edwards, Henk Münstermann and Bert Weltens (eds.), Dialect and school. Clevedon: Multilingual Matters.

Thomason, Sarah and Terrence Kaufman

1988 Language contact, creolization and genetic linguistics. Berkeley: University of California Press.

Vandekerckhove, Reinhilde

2009 Dialect loss and dialect vitality in Flanders. Dialect death in Europe? International Journal of Sociology of Language 196/197: 73-97.

Van Hout, Roeland and Henk Münstermann

1988 The multidimensionality of domain configurations. International Journal of the Sociology of Language 74: 107-124. 
Voortman, Berber

1994 Regionale variatie in het taalgebruik van notabelen; een sociolinguïstisch onderzoek in Middelburg, Roermond en Zutphen. Ph.D. thesis, Amsterdam.

Vousten, Rob

1995 Dialect als tweede taal. Linguistische en extra-linguistische aspecten van de verwerving van een Noordlimburgs dialect door standaardtalige jongeren. Ph.D. thesis, University of Nijmegen.

Vousten, Rob, Theo Bongaerts and Uus Knops

1989 Attitudes en het gebruik van dialect als tweede taal. Gramma 13(2): 129-151.

Weijnen, Antonius A.

1966 Nederlandse dialectkunde. Second edition. Assen: Van Gorcum.

Weijnen, Antonius A.

1967 Sociodialectische onderzoekingen in Limburg. In: Jo Daan and Antonius A. Weijnen (eds.), Taalsociologie. Bijdragen en Mededelingen der dialectencommissie van de Koninklijke Akademie van Wetenschappen XXXII: 16-31.

Leonie Cornips, Amsterdam and Maastricht (The Netherlands)

\section{Holland and Utrecht: Phonology and phonetics}

1. Introduction

2. Phenomena

3. Desiderata

4. Atlases

5. References

\section{Introduction}

In many languages of the world the name for the Netherlands is something similar to Holland. In Dutch, however, Holland usually refers only to a specific part of the country, viz. the two provinces North and South Holland. These contain the three largest cities, Amsterdam, Rotterdam and The Hague, and have formed the national cultural and economic centre for many centuries. Informal observation suggests that the name $\mathrm{Hol}$ land refers to all of the Netherlands outside the own region in the parlance of some dialect speakers outside of Holland; for instance, for Limburg speakers 'Holland' might refer to all of the Netherlands except for Limburg.

This explains the pars pro toto of the toponym, but also the special status of the dialects spoken in this region. For the outside observer, North Holland (which includes Amsterdam) and South Holland (which includes Rotterdam and The Hague) as well as the neighbouring very small province of Utrecht (whose capital city bears the same name) are strikingly underrepresented in the literature on Dutch dialectology. For example, the network of informants assigned to these provinces in the recent FAND, MAND and SAND dialect atlases is less finely grained than that for other parts of the Nether- 